\title{
Physicochemical and Technological Studies on Some Local Egyptian Varieties of Fig (Ficus carica L.)
}

\author{
Abou-Farrag, H.T., Abdel-Nabey, A.A., Abou-Gharbia, H.A. \& Osman, H.O.A. ${ }^{1}$
}

\begin{abstract}
Physicochemical properties, nutritive value and ability to processing of Egyptian local varieties of fig namely ${ }^{6}$ Sultani' first crop and main crop and 'El-Abbody' were carried out. The influence of drying conditions such as pretreatments and drying methods and their effects on acceptability, quality, physicochemical properties and storage stability of the dried product were also studied. The results indicated that the blanching at $100^{\circ} \mathrm{C}$ for $2 \mathrm{~min}$ in salt solution (4\%) and sulphuring in $1 \%$ sodium metabisulphite had the highest value for appearance, colour, taste, odour, texture and overall acceptability for both drying methods (hot air and hot air/microwave). In general, moisture content and the total titratable acidity increased, while $\mathrm{pH}$, ascorbic acid, phenolic content, antioxidant capacity, total and free $\mathrm{SO}_{2}$ and anthocyanins decreased during the drying process by the two methods or during the time of storage at room temperature. In addition, the rehydration ratio decreased during storage. After six months storage at room temperature all colour parameters decreased and the colour of dried fig became darker. Dried fig no longer had any microbial growth and can inhibit the spread of fungi and bacteria
\end{abstract}

Keywords: Fig, Ficus carica L., physical and chemical properties, pretreatments and drying

\section{INTRODUCTION}

Fig (Ficus carica, Moraceae), a very nutritive and healthy food, is one of the most widely produced fruits in the world. It is probably originated from Western Asia, and spread to the Mediterranean. Fig plays an important role in nutrition due to the rich carbohydrate content (almost $65-70 \%$ ). Indeed, the amounts of sugars and vitamins are nearly equal to dates. Fig contains essential amino acids and is rich in vitamins A, B1, B2, and $\mathrm{C}$ as well as minerals (Doymaz, 2005).

Fresh figs are very sensitive to microbial spoilage, even under cold storage conditions and are very perishable at room temperature, showing early senescence, fermentation, and decay that limits their storage period and marketing life, due to high moisture and sugar contents. Thus, they have short shelf life and must be preserved in some ways. The fruit is usually consumed fresh or in dried, canned, and preserved forms (Sadhu, 1990 \& Karabulut et al. 2009).

Dried figs can be consumed directly, or as fig paste in production of different desserts and candies. Dried figs are the only known fruit that is allowed to fully ripen and semidry on the tree (Desai and Kotecha, 1995 $\&$ Drusch and Ragab, 2003).

Drying of agricultural products, a common method of natural preservation by reducing the moisture content to a level at which microbial spoilage is minimized and the product is relatively chemically stable has always been a significant contribution to the income of the agricultural societies (Krokida and Marinos-Koouris, 2003 \& Abd El-Ghaffar, 2009).

Mechanical air dehydration has gained importance because it has many advantages over sun-drying. These include: (a) the process is under better sanitary conditions, (b) drying parameters can be accurately set, controlled and changed over the entire processing time, thus a more consistently uniform product can be achieved with less quality degradation (BarbosaCanovas and Vega-Mercado, 1996 \& Tosun and Delen, 1998).

Using convective hot-air drying method in which, food materials are exposed to elevated drying temperatures, leads to an increase in shrinkage and toughness, reduction of both the bulk density and rehydration capacity of the dried product and also causes serious damage in flavour, colour and nutrient content. The major draw-back of convective hot-air drying method, from an energy point of view, is the longer drying period, higher drying temperature and therefore high energy consumption, which may be as high as $6000 \mathrm{~kJ} / \mathrm{kg}$ of water evaporated (Mujumdar and Menon, 1995, Maskan, 2000 \& Alibas, 2007 ).

The desire to reduce the above problems, as well as to achieve fast and effective thermal process lead to the use of microwave and dielectric heating method for food drying. Microwaves are not forms of heat, but rather forms of energy that are manifested as heat through their interaction with materials. It is as if they cause the materials to heat themselves (Bondaruk, et al, 2007).

Microwave energy is rapidly absorbed by water molecules which, consequently, results in rapid evaporation of water and thus higher drying rates. Therefore microwave drying offers significant energy savings, with a potential reduction in drying times of up

\footnotetext{
${ }^{1}$ Food Science and Technology Dept., Fac. of. Agric.,

El-Shatby, Alexandria Univ., 21545, Alexandria, Egypt

Received April 28, 2013, Accepted June 17, 2013
} 
to $50 \%$ in addition to the inhibition of surface temperature of treated material .( Schiffmann, 1995).

Drying conditions or drying equipments can be modified to increase overall efficiencies. Hybrid drying techniques can be used, such as combining vacuum or convective drying with electro-technologies such as microwave, radio frequency and infrared heating (Raghavan et al., 2005).

This research was undertaken to study the physical and chemical properties of some Egyptian local varieties of fig namely (Sultani first crop and main crop and El-Abbody). The influence of the drying conditions such as pretreatments and drying methods and its effect on acceptability, quality, physicochemical properties and storage stability of the dried product were also undertaken.

\section{MATERIALS AND METHODS \\ Materials:}

Fig fruits (Ficus carica L.) 'Sultani' first and second crop and 'El-Abbody' were obtained from Sidi-Krair, Alexandria Governorate, Egypt at the ripe stage in July during the season 2011. The fruits were directly collected from their trees and brought to the laboratory.

\section{Methods:}

\section{Technological methods:}

\section{Fig drying}

Part of figs (Sultani, main crop) was washed thoroughly with tap water (control sample). The other part after washing, was blanched in boiling sodium chloride solution $4 \%$ at $100^{\circ} \mathrm{C}$ for $2 \mathrm{~min}$ (solution to fruit was 2:1 v/w). After rinsing and cooling by tap water to ambient temperature, sulphiting was carried out by dipping the figs in $0.1 \%$ and $1 \%$ sodium metabisulphite solution for $2 \mathrm{~min}$ (solution to fruit was 2:1v/w), (Table 1).

\section{Hot air drying of fig}

The prepared figs were loaded on wire trays $(78 \mathrm{x}$ $38 \mathrm{~cm}$ ) lined with clean muslin cloth at rate of $1.1 \mathrm{~g} /$ $\mathrm{cm}^{2}$ and dried in cabinet Michell dehydrator at $40^{\circ} \mathrm{C}$ for $4 \mathrm{hrs}$ and continued at $55^{\circ} \mathrm{C}$ until the moisture content of the samples reached the equilibrium moisture content
$(13: 15 \%)$. The dried samples were packed in polyethylene bags and stored at room temperature until used.

\section{Hot air/microwave drying}

The prepared figs were loaded over wire trays and dried at $40^{\circ} \mathrm{C}$ for $4 \mathrm{hrs}$ and continued at $55^{\circ} \mathrm{C}$ for 16 hours. The initial dried figs about $1 \mathrm{Kg}$ was placed in glass dish (diameter $28 \mathrm{~cm}$ and $1.7 \mathrm{~cm}$ depth) at the center of the microwave cavity. The cycle for operating the microwave oven was $1 \mathrm{~min}$ ON then 5 min OFF. This cycle was repeated until the moisture content of the samples reached the equilibrium moisture content $(13: 15 \%)$. The dried samples were packed in polyethylene bags and stored at room temperature until used.

\section{Drying curve}

According to Hamed (2008), the pretreated samples were placed in a dryer (oven dryer or microwave dryer). Weight of the pretreated samples was measured in fixed time intervals and recorded as a function of drying time. The drying data obtained were then expressed as moisture ratio (MR) according to the following equation:

$$
\mathrm{MR}=\frac{\mathrm{M}}{\mathrm{Mi}}
$$

Where:

$\mathrm{MR}=$ Moisture ratio

$\mathrm{M}=\%$ Moisture content (dry basis) at the fixed time intervals.

$\mathrm{Mi}=\%$ Initial moisture content (dry basis).

The calculated MR,s were plotted against the drying times to obtain the drying curve.

\section{Sensory evaluation}

Appearance, colour, odour, taste, texture and overall acceptability of tested samples were assessed by ten panelists of Food Science and Technology Department, Faculty of Agriculture, Alexandria University, Egypt, using a numerical (hedonic) rating of 1-10 (1= dislike very much, $10=$ like very much) as described by Abd El-Lahot (2010).

Table 1. Different pretreatments and drying methods of fig

\begin{tabular}{llcl}
\hline Code & $\begin{array}{c}\text { Sodium metabisulphite conc } \\
(\%)\end{array}$ & $\begin{array}{c}\text { Blanching time } \\
(\mathbf{m i n})\end{array}$ & Drying method \\
\hline HA control & 0 & 0 & Hot air drying \\
HAS0.1\% & 0.1 & 2 & Hot air drying \\
HAS1\% & 1 & 2 & Hot air drying \\
HA/MW control & 0 & 0 & Hot air/microwave drying \\
HA/MW S0.1\% & 0.1 & 2 & Hot air/microwave drying \\
HA/MW S1\% & 1 & 2 & Hot air/microwave drying \\
\hline
\end{tabular}




\section{Storage of samples}

The dried samples that had high scores by panelists were packaged in bags of polyethylene and stored for a period of six months at room temperature. Samples were taken for analysis every three months of storage. The experiments were performed in nested design according to Dean and Voss (2005).

\section{Method of analysis: \\ Physical properties:}

Fruit weight of fig varieties were measured by sensitive balance (Jadever, Surg-30*0.01g). Fruit dimensions (length and width), ostiole width and thickness of skin were measured by micrometer. The fruit index was calculated by dividing the width by the length (width/length) according to Polat and Caliskan (2008). Total soluble solids (TSS) \% of fig varieties were determined by using a hand refrectometer (ATAGO, Japan. $0 \approx 50 \%$ ) using the method mention in A.O.A.C. (2000). The $\mathrm{pH}$ values of fresh and dried samples of fig were measured according to El-Abasy (2011). Approximately $5 \mathrm{~g}$ sample was homogenized with $30 \mathrm{ml}$ distilled water in homogenizer for $10 \mathrm{~min}$ and the filtered solution was used for $\mathrm{pH}$ estimation by digital pH meter (Martini, Bench meter Mi 150). Colour of fresh and dried samples of fig was determined using a Hunter Lab Eazy MatchQC (L*, a*, b*) according to Caliskan and Polat (2011). The $\mathrm{L}^{*}$ value represents lightness ( $\mathrm{L}^{*} 0$ for black, $\mathrm{L}^{*} 100$ for white), whereas the $\mathrm{a}^{*}$ scale represents the red/green dimension, with positive values for red and negative ones for green. The b* scale represents the yellow/blue dimension, with positive values for yellow and negative ones for blue. $\mathrm{L}^{*}, \mathrm{a}^{*}$, and $\mathrm{b}^{*}$ values were measured on three different spots in each samples. The results were recorded as the mean of these measurements. The chroma $\left(\mathrm{C}^{*}\right)$ value, calculated as $=\left(a^{* 2}+b^{2}\right)^{1 / 2}$ indicates colour intensity. Hue angle a parameter that has been shown to be effective in predicting visual colour appearance, was calculated using the formula hue $\mathrm{e}^{\circ}=\tan ^{-1}\left(\mathrm{~b}^{*} / \mathrm{a}^{*}\right)$, where $0^{\circ}$ or $360^{\circ}=$ red-purple, $90^{\circ}=$ yellow, $180^{\circ}=$ green, and $270^{\circ}=$ blue.

\section{Chemical analysis:}

Fresh and dehydrated samples of fig varieties were minced in Braun mixer and subjected to the following analysis. Moisture, total, reducing and non reducing sugars, crude protein, crude ether extract, total ash, crude fibre, titratable acidity and ascorbic acid were determined as described by AOAC procedures (2003) unless otherwise stated. Minerals including $\mathrm{Ca}, \mathrm{Mg}$ were measured as described in the AOAC (2000) using Perkin Elmer Atomic Absorption spectrophotometer
(Model 2380). On the other hand, $\mathrm{K}$ and $\mathrm{Na}$ were determined using flame photometer (Model PEP7, U.K.).

Pectin substances were measured according to Bekheit (2002). Fifty g samples were added to $400 \mathrm{ml}$ distilled water and boiled for an hr at a constant volume. The extract was diluted with water to $500 \mathrm{ml}$ in a volumetric flask and then filtered through Whatman paper No. 41. One hundred $\mathrm{ml}$ of the filtrate was diluted with an equal volume of distilled water, ten $\mathrm{ml}$ of $1 \mathrm{~N}$ sodium hydroxide solution were added to the mixture and the solution was allowed to stand overnight, then, fifty $\mathrm{ml}$ of $1 \mathrm{M}$ acetic acid solution were added. After five min later, $25 \mathrm{ml}$ of $1 \mathrm{M}$ calcium chloride solution were added. The mixture was allowed to stand for an hr before boiling for one min, followed by hot filtration through a Whatman filter paper No. 41 previously weighed. The filter paper was washed with hot water until all traces of chloride were eliminated. The filter paper with the precipitate was dried at $105^{\circ} \mathrm{C}$ for $3 \mathrm{hrs}$ and then cooled before weighing. Redrying was carried out for half an hr to ensure that no further weight loss had occurred. The weight of the precipitate represents the weight of the soluble pectin.

The method recommended for determination of total phenols using Folin-Ciocalteau reagent was adapted from Mc Donald et al (2001) \& Konyaloglu et al (2005). Samples (10 g) were extracted by methanol: water (50: 50, v/v) and left for $30 \mathrm{~min}$ with stirring. Test solutions of $0.5 \mathrm{ml}$ were added to $4.0 \mathrm{ml}$ of $1 \mathrm{M} \mathrm{Na}_{2} \mathrm{CO}_{3}$. Five milliliters of Folin-Ciocalteau reagent $(1: 10, \mathrm{v} / \mathrm{v})$ were added and the solutions were allowed to stand at $45^{\circ} \mathrm{C}$ in water bath for $15 \mathrm{~min}$. Absorbance were measured at $750 \mathrm{~nm}$. The blank consisted of all reagents and solvents without test compounds or standard. The standard was gallic acid prepared in concentrations of 50 to $200 \mathrm{mg} / \mathrm{L}$. This is commonly used as a reference compound. The Phenolic concentrations were determined by comparison with the standard calibration curve. Total phenol values were expressed as gallic acid equivalents ( $\mathrm{mg} \mathrm{g}^{-1}$ dry mass).

According to Caliskan and Polate (2011), the total anthocyanin (TA) content was quantified according to the $\mathrm{pH}$ differential method. Absorbance (A) was measured at 520 and $700 \mathrm{~nm}$ in buffers at $\mathrm{pH} 1.0$ and $\mathrm{pH}$ 4.5 where $\left.A=A_{520}-A_{700}\right)$ ph 1.0- $\left(A_{520}-A_{700}\right) p H 4.5$. The buffers were potassium chloride buffer, $0.025 \mathrm{M}$, pH 1.0 and sodium acetate buffer, $0.4 \mathrm{M}, \mathrm{pH} 4.5$ according to Wrlstad et al. (2005). Results were expressed as $\mu \mathrm{g}$ cyaniding-3- rutinoside (molar extinction coefficient of 28,800 and molecular weight of 595.2) (Soloman et al., 2006) equivalents per $g$ fresh weight of fruit. 


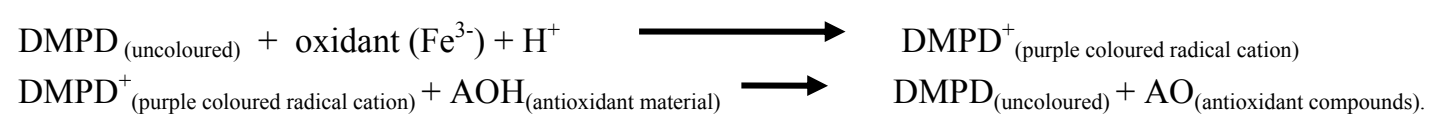

Antioxidant activity was measured by the N,Ndimethyl- $p$-phenylenediamine dihydrochloride (DMPD) according to Fogliano et al (1999). Two hundred and nine $\mathrm{ml}$ of DMPD were dissolved in $10 \mathrm{ml}$ of deionized water. One $\mathrm{ml}$ of this solution was added to $100 \mathrm{ml}$ of $0.1 \mathrm{M}$ acetate buffer $(\mathrm{pH}=5.25)$ then $0.2 \mathrm{ml}$ of $0.05 \mathrm{M}$ ferric chloride solution was added to obtain coloured radical cation $\left(\mathrm{DMPD}^{+}\right)$as follows:

One $\mathrm{ml}$ of this solution was directly placed in a $1 \mathrm{ml}$ plastic cuvette and its absorbance was measured at 505 nm using Spekol Spectrocolorimeter (Spekol 11, Carlzeiss Jena). Standard solution of the antioxidant compound was prepared as follows: A weight of $0.1 \mathrm{~g}$ of ascorbic acid was dissolved in $100 \mathrm{ml}$ of deionized water to obtain $1 \mathrm{mg} / \mathrm{ml}$ of ascorbic acid. $10 \mathrm{~g}$ samples were extracted by $100 \mathrm{ml}$ methanol and then centrifuged. A volume of $50 \mu \mathrm{l}$ of standard antioxidant or sample extraction was added in the spectrometric cuvette contained $1 \mathrm{ml}$ of $\mathrm{DMPD}^{+}$solution, and after 10 min at $25^{\circ} \mathrm{C}$ under continuous stirring, the absorbance was measured at $505 \mathrm{~nm}$. Buffered solution was placed in the reference cuvette.

A dose-response curve was derived for ascorbic acid, by plotting the absorbance at $505 \mathrm{~nm}$ as percentage of the absorbance of the uninhibited radical cation solution according to the following equation:

Inhibition of $\mathrm{A}_{505}(\%)=\left(1-\left(\frac{\mathbf{A F}}{\mathbf{A 0}}\right)\right) \times 100$
Where:

$\mathrm{A} 0=$ absorbance of uninhibited radical cation.

$\mathrm{AF}=$ absorbance measured at $10 \mathrm{~min}$ after the addition of antioxidant samples.

Total and free sulphur dioxide as (ppm) were determined using the iodine titration method as described by Ranganna (1995).

The method recommended by Gouda (1974) was used to determine the rehydration ratio. Ten grams of dried samples were placed in $600 \mathrm{ml}$ beaker and a definite volume $(100 \mathrm{ml})$ of tap water was added, covered by watch glass. Boiling was brought within 3 min and continued for $30 \mathrm{~min}$. The content was then transferred to a Buchnner funnel and left for $1 \mathrm{~min}$ before weighing. Rehydration ratio was expressed as the ratio between the drained weight of the rehydration sample and the weight of the dehydration sample.

\section{Microbiological analysis}

Microbial analysis was carried out aseptically by mixing $10.0 \mathrm{~g}$ of different samples that had the highest scores by panelists along with the control and the stored samples with $90.0 \mathrm{ml}$ sterile $0.1 \%$ peptone water using a blender (stainless steel). Serial dilutions were made. The total aerobic mesophillic bacterial count and yeast/molds count were carried out using nutrient agar at $30^{\circ} \mathrm{C}$ for $48 \mathrm{~h}$ and potato dextrose agar at $25^{\circ} \mathrm{C}$ for $3-$ 5 days, respectively, according to Oztekin et al (2006).

\section{Statistical analysis}

The analysis of data was performed as an analysis of variance (ANOVA) and significant differences were assessed with an LSD test $(\mathrm{p}<0.05)$ according to Dean and Voss (2005) by using statistical software package "STATISTICA 7.0"

\section{RESULTS AND DISCUSSION}

\section{Physical properties of fresh fig}

The physical properties including, weight, length, width, fruit index, ostiole and skin thickness of fresh fig varieties, namely Sultani (first and main crop) and ElAbbody are given in Table (2).

The results indicated that no significant differences were noticed between varieties with respect to their fruit weight. The average fruit weight was higher when compared to the value reported by Shahein and Attalla (1988) and nearly quite similar to that reported by Podgornik et al (2010).

The results shown in Table (2) also indicated that, although there were no significant differences between the three varieties with regard to their width, both length and fruit index of Sultani (first crop) were higher and lower than that of the other two varieties. Length, width and fruit index of Sultani (main crop) and ElAbbody varieties are quite similar to each other.

According to the obtained results, the (globose shape) was observed only for Sultani (first crop) and (oblate shape) was observed for Sultani (main crop) and El-Abbody varieties. These results agreed well with those reported by Abd El-Ghaffar (2009).

As illustrated in Table (2), Sultani (main crop) had the highest value with regard to ostiole width in comparison with the other two varieties. The results obtained in the present study are not in agreement with those reported by Doymaz(2005).

No significant differences were found between the three varieties with regard to skin thickness (top). On the other hand, the skin thickness (center and down) of Sultani (first crop) were slightly higher than that of the other two varieties. 
Table 2. Physical properties of fresh fig ${ }^{*}$

\begin{tabular}{|c|c|c|c|}
\hline \multirow[b]{2}{*}{ Properties } & \multicolumn{3}{|c|}{ Varieties } \\
\hline & $\begin{array}{c}\text { Sultani } \\
\text { (first crop) }\end{array}$ & $\begin{array}{c}\text { Sultani } \\
\text { (main crop) }\end{array}$ & El-Abbody \\
\hline Weight (gm) & $71.31 \pm 12.77^{\mathrm{a}}$ & $65.17 \pm 14.67^{\mathrm{a}}$ & $74.14 \pm 17.34^{\mathrm{a}}$ \\
\hline Length $(\mathrm{cm})$ & $5.86 \pm 0.49^{\mathrm{a}}$ & $4.71 \pm 0.56^{\mathrm{b}}$ & $4.93 \pm 0.67^{\mathrm{b}}$ \\
\hline Width $(\mathrm{cm})$ & $5.30 \pm 0.57^{\mathrm{a}}$ & $5.56 \pm 0.88^{\mathrm{a}}$ & $5.58 \pm 0.85^{\mathrm{a}}$ \\
\hline Fruit index (width/length) & $0.91 \pm 0.12^{\mathrm{b}}$ & $1.19 \pm 0.20^{\mathrm{a}}$ & $1.15 \pm 0.22^{\mathrm{a}}$ \\
\hline Ostiole width $(\mathrm{cm})$ & $0.50 \pm 0.23^{\mathrm{b}}$ & $1.63 \pm 0.58^{\mathrm{a}}$ & $1.09 \pm 0.54^{\mathrm{ab}}$ \\
\hline Skin thickness (top) $(\mu \mathrm{m})$ & $126 \pm 53^{\mathrm{a}}$ & $142 \pm 2^{\mathrm{a}}$ & $137 \pm 13^{\mathrm{a}}$ \\
\hline Skin thickness (center) $(\mu \mathrm{m})$ & $186 \pm 40^{\mathrm{a}}$ & $118 \pm 16^{\mathrm{b}}$ & $140 \pm 26^{b}$ \\
\hline Skin thickness (down) (um) & $315 \pm 126^{\mathrm{a}}$ & $219 \pm 18^{\mathrm{b}}$ & $223 \pm 39^{b}$ \\
\hline T.S.S (\%) & $19.32 \pm 0.9^{\mathrm{a}}$ & $18.6 \pm 0.7^{\mathrm{a}}$ & $16.7 \pm 0.3^{b}$ \\
\hline $\mathrm{pH}$ & $5.28 \pm 0.03^{\mathrm{a}}$ & $5.50 \pm 0.02^{\mathrm{b}}$ & $5.42 \pm 0.03^{\mathrm{c}}$ \\
\hline Titratable acidity $(\%)^{* *}$ & $0.21 \pm 0.01^{\mathrm{a}}$ & $0.12 \pm 0.01^{\mathrm{b}}$ & $0.14 \pm 0.01^{\mathrm{c}}$ \\
\hline Titratable acidity (\%) ${ }^{* * *}$ & $0.96 \pm 0.02^{\mathrm{a}}$ & $0.57 \pm 0.05^{\mathrm{b}}$ & $0.80 \pm 0.03^{c}$ \\
\hline T.S.S./Acidity & $90.6 \pm 2.41^{\mathrm{a}}$ & $155.8 \pm 15.48^{\mathrm{b}}$ & $122.06 \pm 4.55^{\mathrm{c}}$ \\
\hline $\mathrm{L}^{*}$ & $36.11 \pm 5.78^{b}$ & $46.36 \pm 4.80^{\mathrm{a}}$ & $32.37 \pm 2.63^{b}$ \\
\hline$a^{*}$ & $12.89 \pm 4.23^{\mathrm{a}}$ & $11.19 \pm 3.59^{\mathrm{ab}}$ & $7.69 \pm 0.81^{\mathrm{b}}$ \\
\hline$b^{*}$ & $11.19 \pm 5.94^{\mathrm{a}}$ & $17.06 \pm 5.33^{\mathrm{a}}$ & $1.50 \pm 1.48^{\mathrm{b}}$ \\
\hline Chroma & $17.26 \pm 6.71^{\mathrm{a}}$ & $20.94 \pm 3.71^{\mathrm{a}}$ & $7.93 \pm 1.02^{\mathrm{b}}$ \\
\hline Hue & $39.50 \pm 9.29^{b}$ & $55.23 \pm 14.43^{\mathrm{a}}$ & $10.54 \pm 9.59^{\mathrm{c}}$ \\
\hline
\end{tabular}

*Mean \pm S.D.

Means in a row not sharing the same superscript are significantly different at $\leq 0.5$

** As (\%) citric acid on wet weight basis

*** As (\%) citric acid on dry weight basis

Table (2) shows the total soluble solids (T.S.S.), pH, titratable acidity and T.S.S./acidity ratio. Except T.S.S. of Sultani (first crop) and Sultani (main crop) which had similar values of T.S.S., being 19.32 and $18.6 \%$, respectively, all the studied parameters including, T.S.S, $\mathrm{pH}$, titratable acidity and T.S.S./acidity varied between the three studied varieties. For Example, $\mathrm{pH}$ value, titratable acidity and T.S.S./acidity varied between 5.28 to $5.50,0.12$ to $0.21 \%$ and from 90.6 to 155.8 , respectively.These results agreed well with those reported by Shahein and Attalla (1988), Piga et al (2004), Polat and Caliskan (2008) \& Crisosto et al (2010).

The colour parameters $\mathrm{L}^{*}, \mathrm{a}^{*}, \mathrm{~b}^{*}$, chroma and hue values of fresh fig were determined and presented in Table (2).

It is obvious that there were no significant differences on lightness between Sultani (first crop) and Sultani (main crop), while, El-Abbody had the lowest lightness value because of its darker colour. These values were slightly lower than those mentioned by Polat and Caliskan (2008).

\section{Chemical composition of fresh fig}

Table (3) shows the chemical composition of the three varieties of fresh fig. The moisture content of the three varieties ranged from 77.81 to $82.91 \%$. ElAbbody had the highest moisture content and Sultani (first crop) had the lowest moisture content. The results indicated that there are no significant differences between moisture content of Sultani (first crop) and Sultani (main crop). The values obtained here were within the range reported by Hassan (1995), Abd ElMoitte(1996), Amer (1999), Piga et al (2004), Doymaz (2005), Xanthopoulos et al (2007)and Abd El-Ghaffar (2009). They stated that the initial moisture content of the fresh fig fruits is normally ranged from $71 \%$ to $80 \%$. El-Abbody variety was slightly higher in its moisture content than the values reported by the previous authors. On the other hand, the moisture content of the three studied fig varieties in the present work was lower than that reported by Shahein and Attalla (1988).

The results in Table (3) also indicated that the three varieties of fresh figs had similar values of total sugars being $75.63,73.76$ and $73.49 \%$ for Sultani (first crop), Sultani (main crop) and El-Abbody, respectively. ElAbbody fig variety had the lowest amount of reducing sugars and the highest amount of non-reducing sugars in comparison with Sultani variety either the first crop or the main crop. The total amount of reducing sugars varied from $63.49 \%$ to $71.10 \%$, while non-reducing sugars ranged between 4.53 to $10.0 \%$. The results indicated that sugar content of fresh fig are mainly or entirely present as reducing sugars. The obtained results are in agreement with those reported by Kim (1981), 
Marshlkin et al (1986) \& Hassan (1995). They stated that the total sugars and reducing sugar content of fresh fig fruits varied from 67.74 to $89.63 \%$ and from 65.28 to $88.40 \%$, respectively. El-Abbody variety was slightly low in its content of reducing sugars. On the other hand, Abd El-Ghaffar (2009) mentioned that, the nonreducing sugars of fig varieties were $2.21 \%$ which are lower than the values obtained in the present study.

Crude protein content of the three figs varieties ranged from 4.15 to $5.38 \%$ on dry weight basis as shown in Table (3). Sultani (first crop) had the highest protein content and Sultani (main crop) had the lowest protein content. No significant differences were found between Sultani (main crop) and El-Abbody variety. Crude protein content of Sultani (first crop) was in the range reported by Gouda (1974) \& Abd El-Ghaffar (2009). They reported that the protein content varied from 5.22 to $7.20 \%$, while, the protein content of Sultani (main crop) and El-Abbody were lower than the value reported by the previous authors.

According to the obtained results presented in Table (3), the total amount of crude ether extract was very low and ranged from 0.75 to $1.20 \%$ (on dry weight basis). These results are lower than those reported by Farahnaky et al (2009) \& Pande and Akoh (2010).

Total pectin content showed significant differences between the three studied varieties and varied between 3.52 to $9.56 \%$.

The values of crude fibre for Sultani (first crop), Sultani (main crop) and El-Abbody were 5.17, 3.91 and $4.82 \%$ (on dry weight basis), respectively. No significant differences were noticed between Sultani (first crop) and El-Abbody with respect to their content of crude fibre. The amount of crude fibre detected in the

Table 3. Chemical composition of fresh fig

\begin{tabular}{lccc} 
& & Varieties $^{*}$ & Sultani \\
Component $^{* *}$ & $\begin{array}{c}\text { Sultani } \\
\text { (first crop) }\end{array}$ & $\begin{array}{c}\text { El-Abbody } \\
\text { (main crop) }\end{array}$ & $82.91 \pm 0.13^{\mathrm{b}}$ \\
\cline { 2 - 4 } & $77.81 \pm 0.40^{\mathrm{a}}$ & $79.0 \pm 0.07^{\mathrm{a}}$ & $73.49 \pm 1.86^{\mathrm{a}}$ \\
\hline Moisture (\%) & $75.63 \pm 1.89^{\mathrm{a}}$ & $73.76 \pm 0.89^{\mathrm{a}}$ & $63.49 \pm 4.04^{\mathrm{b}}$ \\
Total sugars (\%) & $71.10 \pm 1.17^{\mathrm{a}}$ & $66.91 \pm 1.20^{\mathrm{ab}}$ & $10.0 \pm 1.08^{\mathrm{c}}$ \\
Reducing sugars (\%) & $4.53 \pm 0.79^{\mathrm{a}}$ & $6.85 \pm 1.21^{\mathrm{b}}$ & $4.44 \pm 0.06^{\mathrm{b}}$ \\
Non-reducing sugars (\%) & $5.38 \pm 0.28^{\mathrm{a}}$ & $4.15 \pm 0.07^{\mathrm{b}}$ & $0.75 \pm 0.04^{\mathrm{b}}$ \\
Crude protein (\%) & $1.070 .06^{\mathrm{a}}$ & $1.200 .10^{\mathrm{a}}$ & $9.56 \pm 0.39^{\mathrm{c}}$ \\
Crude ether extract (\%) & $4.59 \pm 0.19^{\mathrm{a}}$ & $3.52 \pm 0.17^{\mathrm{b}}$ & $4.82 \pm 0.20^{\mathrm{a}}$ \\
Total pectin (\%) & $5.17 \pm 0.54^{\mathrm{a}}$ & $3.91 \pm 0.36^{\mathrm{b}}$ & $3.08 \pm 0.09^{\mathrm{c}}$ \\
Crude fibre (\%) & $2.88 \pm 0.11^{\mathrm{a}}$ & $2.53 \pm 0.05^{\mathrm{b}}$ & $561.7 \pm 15.6^{\mathrm{b}}$ \\
Total ash (\%) & $319.3 \pm 18.3^{\mathrm{c}}$ & $611 \pm 24.4^{\mathrm{a}}$ & $254.7 \pm 16.7^{\mathrm{c}}$ \\
Calcium (ppm) & $301.7 \pm 13.7^{\mathrm{a}}$ & $276.6 \pm 12.6^{\mathrm{b}}$ & $885.3 \pm 20.5^{\mathrm{b}}$ \\
Magnesium (ppm) & $832.5 \pm 37.8^{\mathrm{a}}$ & $698.6 \pm 24.8^{\mathrm{c}}$ & $5060.1 \pm 40.6^{\mathrm{a}}$ \\
Sodium (ppm) & $4913.1 \pm 45.3^{\mathrm{b}}$ & $4605.3 \pm 39.0^{\mathrm{c}}$ & \\
Potassium (ppm) & & & 5.106 \\
\hline
\end{tabular}
obtained by Gouda (1974).

As presented in Table (3), total ash content of the three fig varieties ranged from 2.53 to $3.08 \%$ (on dry weight basis). Sultani (first crop) was found to contain the smallest amount of total ash content, while, ElAbbody contained the highest amount of total ash. These values agreed well with those reported by Abd El-Ghaffar (2009).

Calcium, magnesium, sodium and potassium of the three fig varieties are shown in Table (3). The concentration of these minerals ranged from 319.3 to $611.0,254.7$ to $301.7,698.6$ to 885.3 and 4605.3 to $5060.1 \mathrm{ppm}$ (on dry weight basis) for $\mathrm{Ca}, \mathrm{Mg}, \mathrm{Na}$ and $\mathrm{K}$, respectively.

Ascorbic acid, Phenolic content, total anthocyanins and total antioxidant capacity of the three fig varieties are presented in Table (4). Ascorbic acid content in the three fig varieties ranged from 2.16 to $6.71 \mathrm{mg} / 100 \mathrm{gm}$ (on fresh weight basis) and from 10.30 to 30.25 $\mathrm{mg} / 100 \mathrm{gm}$ (on dry weight basis). Sultani (first crop) had the highest ascorbic acid content, while, Sultani (main crop) had the lowest content. Ascorbic acid content of El-Abbody and Sultani (main crop) are in agreement with those reported by Piga et al (2004). They stated that the ascorbic acid content was 12.56 $\mathrm{mg} / 100 \mathrm{gm}$ (on dry weight basis). The results shown in Table (4) indicated that the Phenolic content of the three fig varieties was $0.82,0.50$ and $0.59 \mathrm{mg}$ gallic acid $/ \mathrm{g}$ (on fresh weight basis), and was 3.73, 2.38 and $3.40 \mathrm{mg}$ gallic acid/g (on dry weight basis) for Sultani (first crop), Sultani (main crop) and El-Abbody, respectively. According to these values, no significant differences were found between Sultani (first crop) and El-Abbody. fig varieties in the present study was lower than that

Mean \pm S.D.

Means in a row not sharing the same superscript are significantly different at $\leq 0.5$

** (\%) On dry weight basis. 
Table 4. Ascorbic acid, total phenolic, total anthocyanin content and total antioxidant capacity of fresh fig

\begin{tabular}{lccc}
\hline Component & \multicolumn{3}{c}{ Varieties $^{*}$} \\
\cline { 2 - 4 } & $\begin{array}{c}\text { Sultani } \\
\text { (first crop) }\end{array}$ & $\begin{array}{c}\text { Sultani } \\
\text { (main crop) }\end{array}$ & El-Abbody \\
\hline $\begin{array}{l}\text { Ascorbic acid } \\
(\mathrm{mg} / 100 \mathrm{~g} \text { wet weight basis) }\end{array}$ & $6.71 \pm 0.4^{\mathrm{a}}$ & $2.16 \pm 0.1^{\mathrm{b}}$ & $2.44 \pm 0.1^{\mathrm{b}}$ \\
$\begin{array}{l}\text { Ascorbic acid } \\
(\mathrm{mg} / 100 \mathrm{~g} \text { dry weight basis) }\end{array}$ & $30.25 \pm 1.92^{\mathrm{a}}$ & $10.30 \pm 0.58^{\mathrm{b}}$ & $14.28 \pm 0.51^{\mathrm{c}}$ \\
$\begin{array}{l}\text { Phenolic content } \\
(\mathrm{mg} / \mathrm{g} \text { wet weight basis })^{* *}\end{array}$ & $0.82 \pm 0.07^{\mathrm{a}}$ & $0.50 \pm 0.06^{\mathrm{b}}$ & $0.59 \pm 0.05^{\mathrm{b}}$ \\
$\begin{array}{l}\text { Phenolic content } \\
(\mathrm{mg} / \mathrm{g} \text { dry weight basis })\end{array}$ & $3.73 \pm 0.33^{\mathrm{a}}$ & $2.38 \pm 0.29^{\mathrm{b}}$ & $3.40 \pm 0.29^{\mathrm{a}}$ \\
$\begin{array}{l}\text { Total anthocyanin } \\
(\mu \mathrm{g} / \mathrm{g} \text { wet weight basis) }\end{array}$ & $128 \pm 2^{\mathrm{a}}$ & $38 \pm 5^{\mathrm{b}}$ & $50 \pm 3^{\mathrm{c}}$ \\
$\begin{array}{l}\text { Total anthocyanin } \\
(\mu \mathrm{g} / \mathrm{g} \text { dry weight basis) }\end{array}$ & $577 \pm 9^{\mathrm{a}}$ & $181 \pm 22^{\mathrm{b}}$ & $291 \pm 18^{\mathrm{c}}$ \\
$\begin{array}{l}\text { TAC } \\
(\mathrm{mg} / \mathrm{g} \text { wet weight basis) }\end{array}$ & $2.07 \pm 0.01^{\mathrm{a}}$ & $1.12 \pm 0.11^{\mathrm{b}}$ & $1.28 \pm 0.08^{\mathrm{b}}$ \\
$\begin{array}{l}\text { TAC } \\
(\mathrm{mg} / \mathrm{g} \text { dry weight basis })\end{array}$ & $9.35 \pm 0.46^{\mathrm{a}}$ & $5.33 \pm 0.50^{\mathrm{c}}$ & $7.51 \pm 0.47^{\mathrm{b}}$ \\
\hline
\end{tabular}

* Mean \pm S.D.

Means in a row not sharing the same superscript are significantly different at $\leq 0.5$

** mg gallic acid.

*** $\mu \mathrm{g}$ cyanidin-3-rutinoside.

**** TAC is Total Antioxidant Capacity as ascorbic acid equivalent

These values are within the range mentioned by Caliskan and Polat (2011). The total anthocyanins of the three varieties of fig varied from 38 to $128 \mu \mathrm{g} / \mathrm{g}$ on fresh weight basis as Cyanidine-3-rutinoside and varied from 181 to $577 \mu \mathrm{g} / \mathrm{g}$ on dry weight basis. Sultani (first crop) had the highest anthocyanin content, while, Sultani (main crop) had the lowest amount. These values are in the range presented by Caliskan and Polat (2011). The high content of anthocyanins on Sultani (first crop) may be due to the purple layer present under the skin. The total antioxidant capacity values were 2.07, 1.28 and 1.12 ( $\mathrm{mg}$ ascorbic acid equivalent/g fresh weight basis), and were 9.35, 7.51 and $5.3312(\mathrm{mg}$ ascorbic acid equivalent/g dry weight basis) for Sultani (first crop), Sultani (main crop) and El-Abbody, respectively.

Effect of pretreatments and the drying methods on the drying behaviour of fig

The drying curves of all conducted drying tests are illustrated in Figs (1\&2). The moisture ratio (MR) was plotted versus drying time for the different pretreatments and the different drying methods. As seen in Fig (1), the pretreatments of fig fruit remarkably affected the drying rate. The drying time required to achieve the final moisture content $(13: 15 \%)$ was 2841.3, 2192 and $1923.7 \min (47.36,36.53$ and 32.06 hr) for control, HAS0.1\% and HAS1\%, respectively.

The results obtained here agreed well with those reported by Piga et al (2004). Figs (2\&3) show the effect of drying by hot air/microwave on the drying rate of fig. Drying by hot air/microwave had great effect on reduction the drying time. The drying time decreased from 2841.3 to $1801.7,2192$ to 1423 and 1923.7 to $1436.7 \mathrm{~min}$ (47.36 to $30.03,36.53$ to 23.72 and 32.06 to $23.95 \mathrm{hr}$ ) for control, blanching followed by sulphiting with $0.1 \%$ sodium metabisulphite and blanching followed by sulphiting $1 \%$ with sodium metabisulphite, respectively. The reduction of drying time was in the range of that reported by Prabhanjan et al (1995). They stated that, hot air/hot air/microwave drying of carrot cubes resulted in substantial decrease (25-90\%) in the drying time and the product quality was better when dried at the lower level.

\section{Effect of pretreatments and drying methods on the organoleptic characteristics of dried fig.}

The organoleptic properties of fig samples dried either by hot air or by hot air/microwave are shown in Table (5). As seen from the obtained results, sample HAS $1 \%$ and HA/MW S1\% are highly acceptable compared with the other samples. Except the overall acceptability, no significant differences were noticed between the two samples. These two samples had the highest colour score which may be due to the highest concentration of sulphur during sulphuring process before drying. 


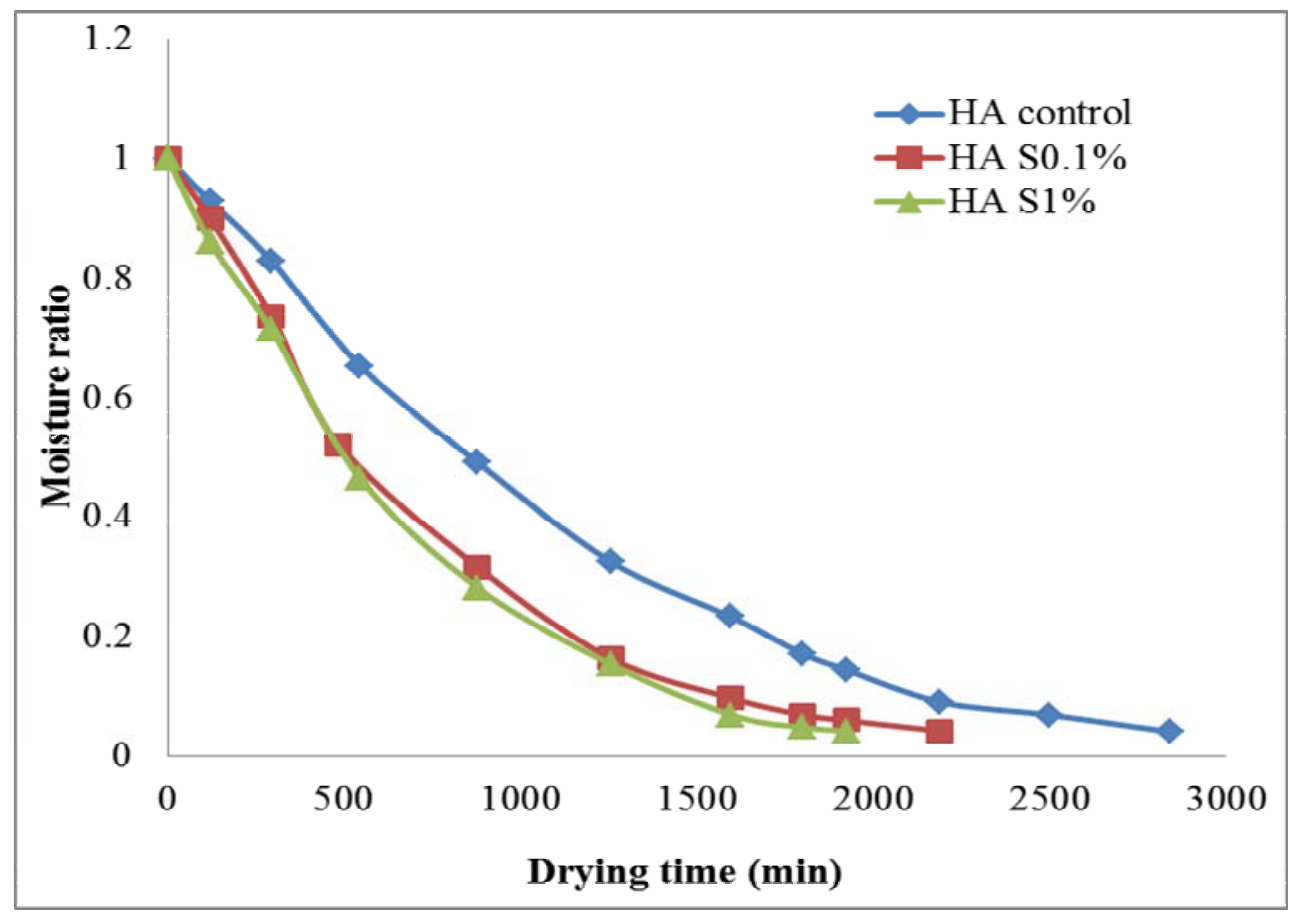

Fig 1. Hot air drying curves of fig at different pretreatments

HA control $=$ control sample that dried by hot air

HA S $0.1 \%=$ blanching and sulphiting with $0.1 \%$ sodium metabisulphite and dried by hot air HA S $1 \%$ = blanching and sulphiting with $1 \%$ sodium metabisulphite and dried by hot air

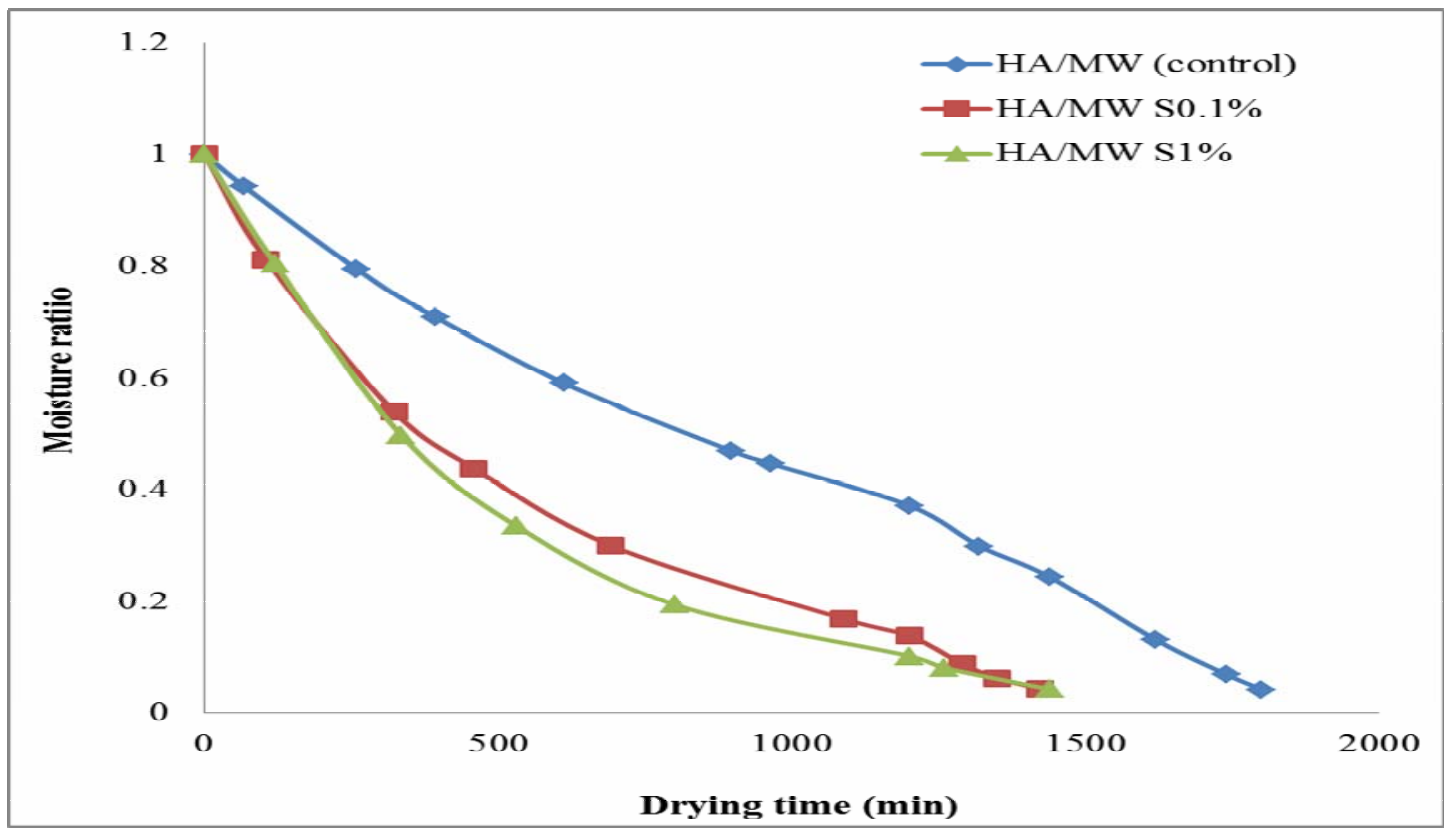

Fig 2. Hot air/microwave drying curves of fig at different pretreatments

HA/MW control = control sample that dried by hot air/microwave

HA/MW S0.1\% = blanching and sulphiting with $0.1 \%$ sodium metabisulphite and dried by hot air/microwave $\mathrm{HA} / \mathrm{MW} \mathrm{S1} \%$ = blanching and sulphiting with $1 \%$ sodium metabisulphite and dried by hot air/microwave 


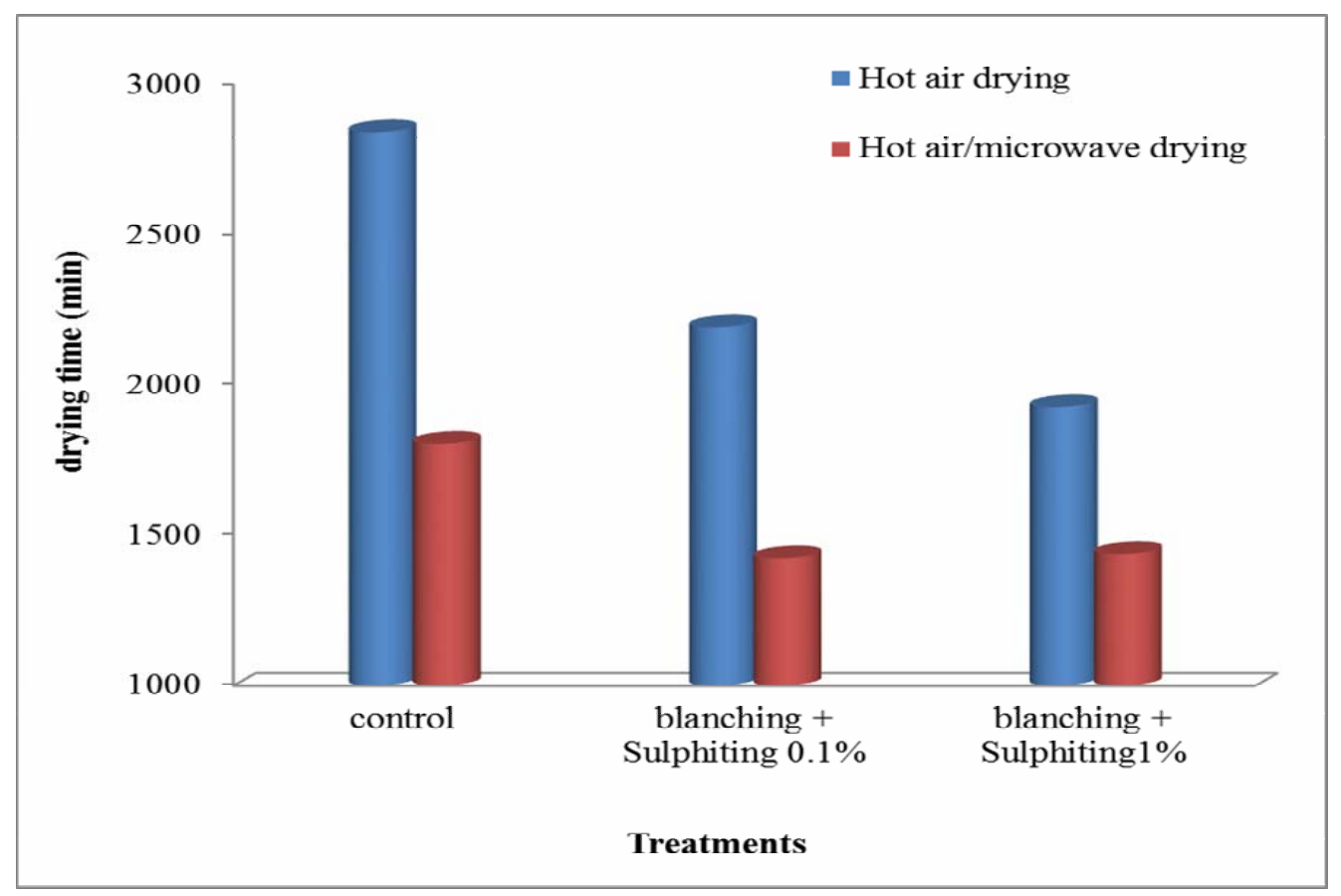

Fig 3. Drying time of fig at different pretreatments and drying methods

Table 5. Effect of pretreatments and drying methods on the organoleptic characteristics of dried fig*"

\begin{tabular}{|c|c|c|c|c|c|c|}
\hline Treatment & Appearance & Colour & Odour & Taste & Texture & $\begin{array}{c}\text { Overall } \\
\text { acceptability }\end{array}$ \\
\hline HAS $1 \%$ & $7.6 \pm 1.1^{\mathrm{a}}$ & $7.7 \pm 1.1^{\mathrm{a}}$ & $6.8 \pm 1.3^{\mathrm{a}}$ & $6.9 \pm 1.6^{\mathrm{ab}}$ & $7.1 \pm 1.7^{\mathrm{a}}$ & $8.25 \pm 0.8^{\mathrm{a}}$ \\
\hline HAS $0.1 \%$ & $5.5 \pm 1.2^{\mathrm{b}}$ & $5.2 \pm 1.4^{\mathrm{b}}$ & $5.5 \pm 1.5^{\mathrm{b}}$ & $6.4 \pm 1.2^{\mathrm{ab}}$ & $6.8 \pm 1.1^{\mathrm{a}}$ & $6.1 \pm 0.8^{\mathrm{c}}$ \\
\hline HA control & $3.2 \pm 1.6^{\mathrm{c}}$ & $2.6 \pm 1.8^{\mathrm{d}}$ & $4.3 \pm 1.7^{\mathrm{c}}$ & $5 \pm 1.7^{\mathrm{c}}$ & $5.3 \pm 2.4^{\mathrm{b}}$ & $4.0 \pm 0.9^{\mathrm{e}}$ \\
\hline HA/MW S $1 \%$ & $6.8 \pm 1.9^{\mathrm{a}}$ & $7.2 \pm 1.4^{\mathrm{a}}$ & $6.2 \pm 1.7^{\mathrm{ab}}$ & $6.1 \pm 1.7^{\mathrm{abc}}$ & $6.9 \pm 2.0^{\mathrm{a}}$ & $7.1 \pm 0.7^{\mathrm{b}}$ \\
\hline HA/MW S0.1\% & $5.5 \pm 1.7^{b}$ & $5.6 \pm 1.6^{\mathrm{b}}$ & $5.6 \pm 1.6^{\mathrm{b}}$ & $5.5 \pm 1.5^{\mathrm{bc}}$ & $6.5 \pm 1.6^{\mathrm{ab}}$ & $5.6 \pm 0.7^{\mathrm{cd}}$ \\
\hline HA/MW control & $4.8 \pm 1.2^{\mathrm{b}}$ & $3.9 \pm 1.7^{\mathrm{c}}$ & $5.5 \pm 1.5^{b c}$ & $5.9 \pm 1.7^{\mathrm{abc}}$ & $6.3 \pm 1.4^{\mathrm{ab}}$ & $5.1 \pm 0.7^{\mathrm{d}}$ \\
\hline
\end{tabular}

\section{* Mean \pm S.D.}

Means in a column not sharing the same superscript are significantly different at $\leq 0.5$

HA control $=$ control sample that dried by hot air

HA S $0.1 \%$ = blanching and sulphiting with $0.1 \%$ sodium metabisulphite and dried by hot air

HA S $1 \%$ = blanching and sulphiting with $1 \%$ sodium metabisulphite and dried by hot air

$\mathrm{HA} / \mathrm{MW}$ control = control sample that dried by hot air/microwave

HA/MW S0.1\% = blanching and sulphiting with $0.1 \%$ sodium metabisulphite and dried by hot air/microwave

HA/MW S1\% = blanching and sulphiting with $1 \%$ sodium metabisulphite and dried by hot air/microwave

Also, the results shown in Table (5) revealed that the control sample dried either by hot air and by hot air/microwave are not accepted by panelists. On the other hand, samples HAS0.1\% and HA/MW S0.1\% are slightly accepted by panelists. Based on the obtained results, the storage experiments were carried out only on sample HAS1\% (blanched for $2 \mathrm{~min}$ in $4 \% \mathrm{NaCl}$ solution and sulphited in 1\% sodium metabisulphite and dried by hot air dryer) and sample HA/MW S1\% (blanched for $2 \mathrm{~min}$ in $4 \% \mathrm{NaCl}$ solution and sulphited in $1 \%$ sodium meta bisulphate and dried by hot air/microwave).

\section{Effect of pretreatments, drying methods and storage on quality of dried fig}

Moisture content is considered as one of the most important components in foods, and rate of various deterioration which occur in dehydrated foods. In the present trial, the most acceptable samples of fig dried by hot air (HAS1\%) and that dried by hot air/microwave (HA/MW S1\%) previously determined by sensory evaluation, were tightly packed in polyethylene pouches under atmospheric pressure and stored at room temperature for six months and the moisture content 
was determined and presented in Table (6). The moisture content decreased from $79 \%$ (fresh sample) to 13.71 and $13.02 \%$ for sample HAS1\% and HA/MW $\mathrm{S} 1 \%$, respectively. The results revealed that the moisture content of all samples under investigation increased during the storage period. After storage for six months, the moisture content increased to18.86 and $16.06 \%$ for sample HAS1\%and HA/MW S1\%, respectively.

As seen from the results in Table (6), ascorbic acid content decreased by increasing the storage time. The reduction in ascorbic acid was significantly higher for sample dried by hot air than that dried by hot air/microwave. Ascorbic acid content reduced from 5.12 to 4.06 and from 6.60 to $5.60 \mathrm{mg} / 100 \mathrm{~g}$ (on dry weight basis) for sample HAS1\% and sample HA/MW S1\%, respectively, during the storage period. The results obtained here are higher than that reported by Gouda (1974) and nearly close to that reported by Piga et al (2004).

The results also revealed that the drying process reduced the phenolic content, and the percentages of reduction were found to be 28.57 and $15.55 \%$ for sample HAS1\% and sample HA/MW S1\%, respectively. The reduction in phenolic content may be due to pretreatments and the drying process. From the statistical point of view and during storage, the reduction of phenolic content was slightly lower in sample dried by hot air/microwave due to the short period of drying during this process. At the beginning of the storage period, phenolic contents were 1.70 and $2.01 \mathrm{mg}$ gallic acid/g sample (on dry weight basis) for sample HAS1\% and HA/MW S1\%, respectively. The reduction in phenolic content increased by increasing storage time and sample $\mathrm{HAS} 1 \%$ that stored for six months had the lowest phenolic content and it was 1.48 $\mathrm{mg}$ gallic acid/g sample (on dry weight basis).

In addition, the results indicated that the drying process led to a significant reduction in antioxidant capacity and the loss was found to be 50.09 and 48.22 $\%$ for sample HAS1\% and sample HA/MW S1\%, respectively. The reduction in antioxidant capacity may be due to the pretreatments such as blanching and the relatively high temperature applied during the drying process. At the end of storage period (6 months), antioxidant capacity decreased to $1.06 \mathrm{mg}$ ascorbic acid equivalent/g sample (on dry weight sample) for HAS1\% and $\mathrm{HA} / \mathrm{MW} \mathrm{S} 1 \%$.

Sulphur dioxide is considered to be one of the most important factors that affect quality attributes and prevent colour and quality deterioration of dried fruit during storage. From the results shown in Table (6) it could be noticed that the residual amount of total $\mathrm{SO}_{2}$ after drying was 298.4 and 324.7 ppm for samples
HAS $1 \%$ and HA/MW S1\%, respectively. On the other hand, the residual amount of free $\mathrm{SO}_{2}$ after drying was 130.4 and 150.4 ppm for samples $\mathrm{HAS} 1 \%$ and $\mathrm{HA} / \mathrm{MW}$ $\mathrm{S} 1 \%$, respectively. The residual amount of $\mathrm{SO}_{2}$ after drying was lower than that reported by Gouda (1974), Hassan (1995) \& Abd El-Ghaffar (2009). This may be due to the increasing amount of initial $\mathrm{SO}_{2}$ and the long period of exposure during the sulphuring process. The residual amount of $\mathrm{SO}_{2}$ in the dried fig was highly reduced by storage at room temperature for six months. The losses of total $\mathrm{SO}_{2}$ were 45.07 and $38.50 \%$, and the losses of free $\mathrm{SO}_{2}$ were 52.91 and $54.72 \%$ for samples $\mathrm{HAS} 1 \%$ and $\mathrm{HA} / \mathrm{MW} \mathrm{S1 \%}$, respectively, after three months of storage. Moreover, the losses of total $\mathrm{SO}_{2}$ were 61.23 and $56.27 \%$, and the losses of free $\mathrm{SO}_{2}$ were 76.69 and $75.20 \%$ for samples HAS1\% and HA/MW $\mathrm{S} 1 \%$, respectively, after six months of storage. These results are in accordance with those reported by Hassan (1995), who stated that dried Sultani figs lost about 52 to $62 \%$ from the residual $\mathrm{SO}_{2}$ by storage at room temperature for eight months. As a matter of fact, the residual amount of total and free $\mathrm{SO}_{2}$ after drying and storage for sample $\mathrm{HA} / \mathrm{MW} \mathrm{S1 \%}$ were significantly higher than that reported for sample HAS1\%.

Drying process led to a significant reduction in total anthocyanins and this reduction amounted about $99 \%$ for the treated samples HAS1\% (dried by hot air) and HA/MW S1\% (dried by hot air/microwave). Total anthocyanins decreased from 38.0 to 2.0 and $0.8 \mu \mathrm{g}$ cyanidin-3-rutinoside/g fresh weight basis for HAS1\%

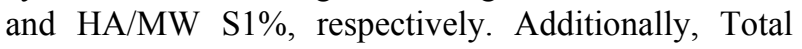
anthocyanins decreased from 181.0 to 2.32 and $0.92 \mu \mathrm{g}$ cyanidin-3-rutinoside/g dry weight basis for HAS1\% and HA/MW S1\%, respectively. This may be due to the high temperature used for blanching $\left(100^{\circ} \mathrm{C}\right)$, $\mathrm{pH}$ of salt solution, the relatively high temperature of air during drying process and elongation of drying time.

The rehydration ratio of dried fig samples is presented in Table (6). The rehydration ratio of the dehydrated fig after drying was 1.80 and 1.47 for HAS $1 \%$ and HA/MW S1\%, respectively. Furthermore, the rehydration ratio decreased during storage and reached to 1.51 and 1.45 after six months for HAS1\%

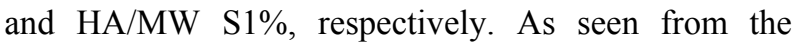
results, HAS1\% sample at zero time had the highest rehydration ratio. After 3 and 6 months of storage, there are no significant differences between samples HAS1\% and $\mathrm{HA} / \mathrm{MW} \mathrm{S1 \%}$ with respect to the rehydration ratio.

The hunter colour scale parameters, redness $\left(a^{*}\right)$, yellowness $\left(b^{*}\right)$ and lightness $\left(\mathrm{L}^{*}\right)$ were used to estimate colour changes after drying process and storage. The results are given in Table (7). Before drying, $L^{*}, a^{*}, b^{*}$, chroma and hue values for fresh fig were $46.36,11.19,17.19,20.94$ and 55.23, respectively. 


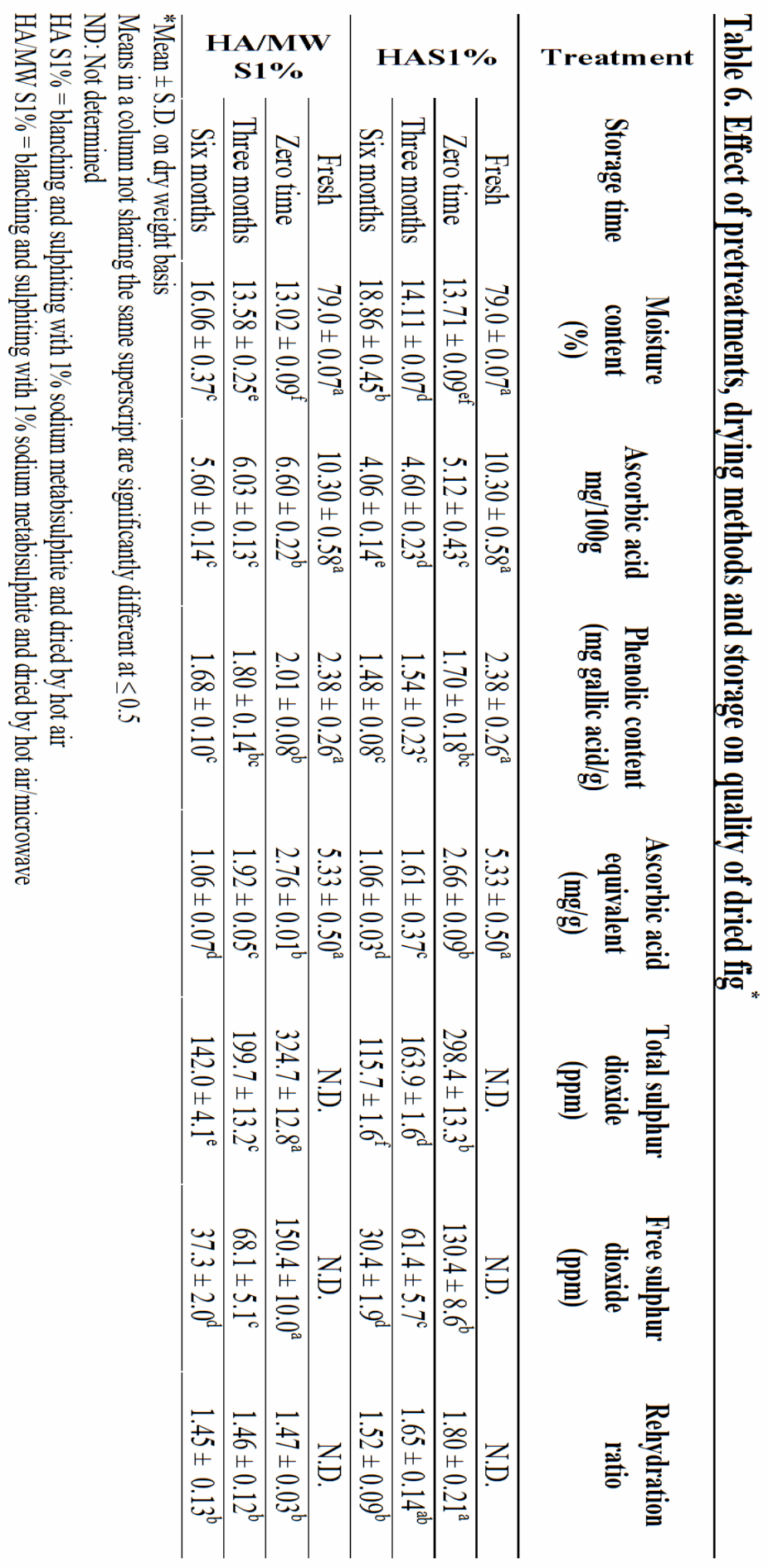


Results in Table (7) show that the drying process decreased lightness in both samples dried by hot air and by hot air/microwave. Lightness $\left(\mathrm{L}^{*}\right)$ reached 42.81 and 31.71 for HAS $1 \%$ and HA/MW S1\%, respectively. This may be due to formation of brown pigments. These values were in the range presented by Piga et al (2004). The same view was observed for redness $\left(\mathrm{a}^{*}\right)$ value but the decrement was not significantly different. On the other hand, $b^{*}$ value increased after drying for both treatments. Yellowness $\left(\mathrm{b}^{*}\right)$ reached 33.9 and 17.29 for $\mathrm{HAS} 1 \%$ and $\mathrm{HA} / \mathrm{MW} \mathrm{S1} \%$, respectively. The increment may be due to sulphuring treatments that bleach the colour. The same view was observed by Abd El-Ghaffar (2009). Chroma and hue angle values were calculated and the results are shown in Table (7). Chroma and hue values of HAS $1 \%$ increased after drying and reached 36.91 and 66.84, respectively. On the other hand chroma and hue values of HA/MW S1\% decreased after drying and reached 20.90 and 51.23, respectively. The effect of storage of dried fig at ambient temperature on colour was also shown in Tables (7). $\mathrm{L}^{*}, \mathrm{a}^{*}$ and $\mathrm{b}^{*}$ values decreased by increasing the storage period and the colour became darker. Chroma and hue values increased after storage for three months for both treatments, whereas, after six months, marketable decreased was observed and chroma value reached 24.59 and 3.81 for HAS1\% and HA/MW S1\%, respectively. Besides, hue values reached 55.53 and

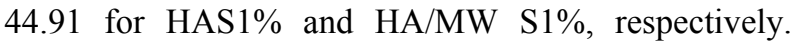
These results were nearly close to that observed by Abd El-Ghaffar (2009).

Aerobic mesophilic counts as well as yeast and molds counts of fig were determined and presented in Table (8).Generally, all counts of sample were less than 25 . Thus, the results are reported as estimated aerobic plate count (EAPC) or estimated yeast and molds counts $($ EYMC $)<250$. It can be noticed from the obtained results that dried fig no longer had any microbial growth and can inhibit the spread of fungi and bacteria.

As a conclusion, blanching at $100^{\circ} \mathrm{C}$ for $2 \mathrm{~min}$ in salt solution (4\%) and sulphuring in $1 \%$ sodium metabisulphite had the highest values for appearance, colour, taste, odour, texture and overall acceptability for both drying methods (hot air and hot air/microwave). The shortest drying time was for the sample dried by hot air/microwave. Dried fig no longer had any microbial growth and can inhibit the spread of fungi and bacteria.

Table 7. Effect of pretreatments, drying methods and storage on on $L^{*}$, $a^{*}$ and $b^{*}$ values of fig*

\begin{tabular}{|c|c|c|c|c|c|c|}
\hline 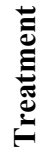 & $\begin{array}{c}\text { Storage } \\
\text { period }\end{array}$ & $\mathbf{L}^{*}$ & $a^{*}$ & $\mathbf{b}^{*}$ & Chroma & Hue \\
\hline \multirow{4}{*}{$\frac{\partial^{0}}{\pi}$} & Fresh & $46.36 \pm 4.80^{\mathrm{a}}$ & $11.19 \pm 3.59^{\mathrm{a}}$ & $17.19 \pm 5.33^{b}$ & $20.94 \pm 3.71^{b}$ & $55.23 \pm 14.43^{\mathrm{b}}$ \\
\hline & $\begin{array}{l}\text { Zero } \\
\text { time }\end{array}$ & $42.81 \pm 4.19^{\mathrm{a}}$ & $14.39 \pm 2.12^{\mathrm{a}}$ & $33.9 \pm 2.99^{\mathrm{a}}$ & $36.91 \pm 1.92^{\mathrm{a}}$ & $66.84 \pm 4.87^{\mathrm{a}}$ \\
\hline & $\begin{array}{l}\text { Three } \\
\text { months }\end{array}$ & $31.11 \pm 1.71^{\mathrm{b}}$ & $12.6 \pm 0.50^{\mathrm{a}}$ & $20.83 \pm 1.18^{b}$ & $24.35 \pm 0.95^{\mathrm{b}}$ & $58.8 \pm 2.02^{\mathrm{ab}}$ \\
\hline & $\begin{array}{c}\text { Six } \\
\text { months }\end{array}$ & $33.21 \pm 1.24^{\mathrm{b}}$ & $13.88 \pm 2.11^{\mathrm{a}}$ & $20.28 \pm 3.29^{b}$ & $24.59 \pm 3.74^{\mathrm{b}}$ & $55.53 \pm 2.74^{b}$ \\
\hline \multirow{4}{*}{ 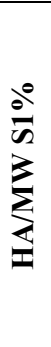 } & Fresh & $46.36 \pm 4.80^{\mathrm{a}}$ & $11.19 \pm 3.59^{\mathrm{a}}$ & $17.19 \pm 5.33^{b}$ & $20.94 \pm 3.71^{b}$ & $55.23 \pm 14.43^{b}$ \\
\hline & $\begin{array}{l}\text { Zero } \\
\text { time }\end{array}$ & $31.71 \pm 9.91^{b}$ & $11.19 \pm 3.84^{\mathrm{a}}$ & $17.29 \pm 14.11^{b}$ & $20.90 \pm 13.95^{b}$ & $51.81 \pm 11.86^{\mathrm{b}}$ \\
\hline & $\begin{array}{c}\text { Three } \\
\text { months }\end{array}$ & $31.9 \pm 5.96^{\mathrm{b}}$ & $12.74 \pm 3.12^{\mathrm{a}}$ & $17.89 \pm 7.81^{\mathrm{b}}$ & $22.02 \pm 8.09^{b}$ & $52.83 \pm 7.02^{\mathrm{b}}$ \\
\hline & $\begin{array}{c}\text { Six } \\
\text { months }\end{array}$ & $21.06 \pm 2.34^{\mathrm{c}}$ & $2.76 \pm 2.01^{b}$ & $2.62 \pm 1.60^{\mathrm{c}}$ & $3.81 \pm 2.56^{\mathrm{c}}$ & $44.91 \pm 3.24^{\mathrm{c}}$ \\
\hline
\end{tabular}

* Mean \pm S.D.

Means in a column not sharing the same superscript are significantly different at $\leq 0.5$

HA S $1 \%=$ blanching and sulphiting with $1 \%$ sodium metabisulphite and dried by hot air

$\mathrm{HA} / \mathrm{MW} \mathrm{S1} \%$ = blanching and sulphiting with $1 \%$ sodium metabisulphite and dried by hot air/microwave 
Table 8. Effect of pretreatments, drying methods and storage on aerobic mesophilic count of fig

\begin{tabular}{|c|c|c|c|c|c|c|c|c|c|}
\hline \multirow{2}{*}{ 苞 } & \multirow[b]{2}{*}{$\begin{array}{l}\text { Storage } \\
\text { time }\end{array}$} & \multicolumn{3}{|c|}{ dilutions } & \multirow[b]{2}{*}{ EAPC } & \multicolumn{3}{|c|}{ dilutions } & \multirow[b]{2}{*}{ EYMC } \\
\hline & & $10^{-1}$ & $10^{-2}$ & $10^{-3}$ & & $10^{-1}$ & $10^{-2}$ & $10^{-3}$ & \\
\hline \multirow{3}{*}{ HAS1\% } & Zero time & 4 & 2 & 1 & $<250$ & 0 & 0 & 0 & $<250$ \\
\hline & $\begin{array}{l}\text { Three } \\
\text { months }\end{array}$ & 5 & 2 & 1 & $<250$ & 0 & 0 & 0 & $<250$ \\
\hline & Six months & 10 & 3 & 1 & $<250$ & 0 & 0 & 0 & $<250$ \\
\hline \multirow{3}{*}{$\begin{array}{c}\text { HA/MW } \\
\text { S1\% }\end{array}$} & Zero time & 2 & 1 & 1 & $<250$ & 0 & 0 & 0 & $<250$ \\
\hline & $\begin{array}{l}\text { Three } \\
\text { months }\end{array}$ & 3 & 0 & 1 & $<250$ & 0 & 0 & 0 & $<250$ \\
\hline & Six months & 14 & 4 & 7 & $<250$ & 7 & 0 & 0 & $<250$ \\
\hline
\end{tabular}

* EAPC estimated aerobic plate counts, EYMC estimated yeasts and molds count

HA S $1 \%=$ blanching and sulphiting with $1 \%$ sodium metabisulphite and dried by hot air

HA/MW S1\% = blanching and sulphiting with $1 \%$ sodium metabisulphite and dried by hot air/microwave

\section{REFERENCES}

Abd El-Ghaffar, E.A. 2009. Astudy on kinetics of drying process of some fruits and vegetables. Ph.D. Thesis, Food Sci. Dept. Fac. of Agric., Ain Shams Univ., Egypt.

Abd El-Lahot, M.S.R. 2010. Effect of roasting and storage processes on chemical and physical properties of coffee. M. Sc. Thesis, food science and technol. Fac. of Agric., Alex. Univ., Egypt.

Abd El-Moitte, S.F. 1996. Effect of drying methods and sulfuring on dried fig quality. M.Sc. Thesis, Food Sci. Dept., Faculty of Agric., Cairo Univ., Egypt.

Alibas,I. 2007 Microwave, air and combined microwave-airdrying parameters of pumpkin slices, LWT-Food Sci. and Technol., 40 : 1445-1451

Amer, B.M. 1999. Determination of drying rate of fruits as a function of the affecting factors under conditions suiting solar drying. M.Sc. Thesis, Agricultural Eng. Dept., Faculty of Agric., Cairo Univ., Egypt.

Association of Official Analytical Chemists (AOAC). 2003. Official methods of analytical .Helrich, K. $17^{\text {th }}$ ed. Virginia, USA.

Association of Official Analytical Chemists (AOAC). 2000. Official methods of analytical. $17^{\text {th }}$ ed. Gaitherburg: Maryland, USA.

Barbosa-Canovas, G.V. \& Vega-Mercado, H. 1996. Other methods of dehydration of foods and packaging aspects. In: Barbosa- Canovas, G.V. and Vega-Mercado, H (Eds.), Dehydration of Foods. New York: Chapman \& Hall: 289320.

Bekheit, A.A.A. 2002. Production and evaluation of Egyptian date sheets and pastes. M. Sc. Thesis, Food Sci. and Tech. Dept. Fac. of Agric., Cairo Univ., Egypt.

Bondaruk, J., Markowski, M. \& Blaszczak, W. 2007. Effect of drying conditions on the quality of vacuum-microwave dried potato cubes. J. Food Eng., 81: 306-312.
Caliskan, O. \& Polat, A.A. 2011. Phytochemical and antioxidant properties of selected fig (Ficus carica L.) accessions from the eastern Mediterranean region of Turkey. Scientia Hort., $128: 473-478$.

Crisosto, C.H., Bremer, V., Ferguson, L. \& Crisosto, G.M. 2010. Evaluating Quality Attributes of Four Fresh Fig (Ficus carica L.) Cultivars Harvested at Two Maturity Stages. Hortscience, 45(4): 707-710.

Dean, A. \& Voss, D. 2005. Design and analysis of experiments springer - Verlag, New York.

Desai, U.T. \& Kotecha, P.M. 1995. Fig. In: Salunke, D.K. and Kadam, S.S (Eds.), Handbook of Fruit Science and Technology. Marcel Dekker Inc., NY: 407-408.

Doymaz, I. 2005. Sun drying of figs: an experimental study. J. Food Eng., 71: 403-407.

Drusch, S. \& Ragab, W. 2003. Mycotoxins in fruits and dried fruits. J. Food Prot. 66: 1514-1527.

El-Abasy, A.E.M. (2011). Formulation and evaluation of some functional juice mixes and bakery products. M.Sc. Thesis, Food Science and Technology Dept. Fac. Of Agric., Alex. Univ. Alexandria, Egypt.

Farahnaky, A., Ansari, S. \& Majzoobi, M. 2009. Effect of glycerol on the moisture sorption isotherms of figs. J. Food Eng., 93: 468-473.

FDA 2000. Bacteriology analtyical manual. FDA, center for food safety and applied nutrition.www.cfsan.fda.gov $\sim$ ebam $\backslash$ bam-3.html

Fogliano, V., Verde, V., Randazzo, G. \& Ritieni, A. 1999. Method for measuring antioxidant activity and its application to monitoring the antioxidant capacity of wines. J. Agric. Food Chem., 47: 1035-1040

Gouda, M.S.M. 1974. Chemical and technological studies on imported varieties planted in Egypt. M. Sc. Thesis, Food Sci. and Tech. Dept. Fac. of Agric., Alex. Univ., Egypt.

Hamed, E.Y. 2008. Drying grapes using microwave. M. Sc. Thesis, Agricultural engineering. Fac. of Agric., Alex. Univ., Egypt. 
Hassan, F. R. H. 1995. Chemical and technological studied on fruit drying of some fig cultivars. M.Sc. Thesis, Food Sci. Dept., Faculty of Agri., Cairo Univ., Egypt.

Karabulut, O.A., Ilhan, K., Arslan, U. \& Vardar, C. 2009. Evaluation of the use of chlorine dioxide by fogging for decreasing postharvest decay of fig. Postharvest Biol. Technol. 52: 313-315.

Kim, K. H. 1981. Chemical composition of Korean figs and its storage stability. Korean. J. Food. Sci. and Tech. 13: 165-169.

Kolesnik, A.A., Kakhniashvili, T. A., Zherebin, Y.L., Golubev, V.N. \& Pilipenko, L. N. 1987. Lipids of the fruit of Ficus carica. Chemistry of Natural Compounds, 22: 394-397.

Konyaloglu, S., Saglam, H. \& Kvcak, B. 2005. a-Tocopherol, flavonoid, and phenol contents and antioxidant activity of ficus carica leaves. Pharmaceutical Biol., 43: 683-686.

Krokida, M.M. and Marinos-Koouris, D. (2003). Rehydration kinetics of dehydrated products. J. Food Eng., 57: 1-7.

Marshlkin, G.A., Pkhakadze, M.D. \& Silagadze, M.A. 1986. Chemical and technological evaluation of figs for conficitionary manufacture. Khlelbopekarnaya ikonditerskaya promyshlennost No.6 : 38-39. C.F. F.S.T.A 19: J88 (1987).

Maskan, M. 2000. Microwave/air and microwave finish drying of banana, J. Food Eng., 44:71-78.

McDonald S. , Prenzler P.D., Antolovich M. \& Robards K. 2001: Phenolic content and antioxidant activity of olive extract. Food Chem. 73: 73-84.

Mujumdar,A.S. \& Menon,A.S. 1995. Drying of solids: principles, classification, and selection of dryers. In: Mujumdar, A.S.(Eds.), Handbook of Industrial Drying. Marcel-Dekker Inc., New York, USA, 1: 1-39.

Oztekin, S., Zorlugenc, B. \& Zorlugenc, F.K (2006). Effects of ozone treatment on micro flora of dried figs. J. Food Eng., 75: 396-399.

Pande, G. \& Akoh, C.C (2010). Organic acids, antioxidant capacity, phenolic content and lipid characterisation of Georgia-grown underutilized fruit crops. Food Chem., 120: $1067-1075$.

Piga, A., Pinna, I., Ozer, K.B., Agabbio, M. \& Aksoy, U (2004). Hot air dehydration of figs (Ficus carica L.): drying kinetics and quality loss. International J. Food Sci. and Technol., 39: 793-799.
Podgornik, M., Vuk, I., Vrhovnik, I. \& Mavsar, D.B. 2010. A survey and morphological evaluation of fig (Ficus carica L.) genetic resources from Slovenia . Scientia Hort., 125: 380-389.

Polat, A.A. \& Caliskan, O. 2008. Fruit characteristics of table fig (Ficus carica) cultivars in subtropical climate conditions of the Mediterranean region. New Zealand J. Crop and Hort. Sci., $36: 107-115$.

Prabhanjan, D.G. , Ramaswamy, H. S. \& Raghavan, G. S. V. 1995. Microwave-assisted convention air drying of thin layer carrots. J. Food Eng., 25: 283-293.

Raghavan, G.S.V., Rennie, T.J., Sunkja, P.S., Orsat, V., Phaphuangwittayakul, W. \& Terdtoon, P. 2005. Overview of new techniques for drying biological materials with emphasis on energy aspects. Braz. J. Chem. Eng., 22: ???????

Ranganna, S. 1995. Handbook of analysis and quality control for fruit and vegetable products. $2^{\text {nd }}$ ed. Tata McGraw-Hill Publishing Company Limited. New Delhi.

Sadhu, M.K. 1990 . Fig. In: Kose, T.K. and Mitra, S.K (Eds.), Fruits: Tropical and Subtropical. Naya Prokash, Calcutta. Pp. 650-663.

Schiffmann, R.F.1995. Microwave and dielectric drying. In: Mujumdar, A.S (Eds.), Handbook of Industrial Drying. New York, USA : 345-372.

Shahein A.H. \& Attalla, A.M. 1988. Evaluation of nutritional status and fruit quality of some fig varieties grown in Rass Abu-Lahw region at the North Western coast of Egypt. Alex. J. agric .res., 33: 195-207.

Solomon, A. , Golubowicz, S., Yablowicz, Z. , Grossman, S., Bergman, M. , Gottlieb, H.E., Altman, A., Kerem, Z. \& Flaishman, M.A. 2006. Antioxidant activities and anthocyanin content of fresh fruits of common fig (Ficus carica L.). J. Agric. Food Chem., 54: 7717-7723.

Tosun, N. \& Delen, N. 1998. Minimising of contaminaton of aflatoxigenic fungi and subsequent aflatoxin development in fig orchards by fungicides. Acta Hort., 480: 193-197.

Wrolstad, R.E., Acree, T.E., Decker, E.A., Penner, M.H., Reid, D.S., Schwartz, S.J., Shoemaker, C.F., Smith, D. \& Sporns, P. 2005. Handbook of Food Analytical Chemistry. John Wiley \& Sons, INC Publication.

Xanthopoulos, G., Oikonomou, N. \& Lambrinos, G. 2007. Applicability of a single layer drying model to predict the drying rate of whole figs. J. Food Eng., 81 : 553-559. 


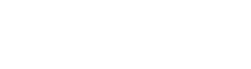

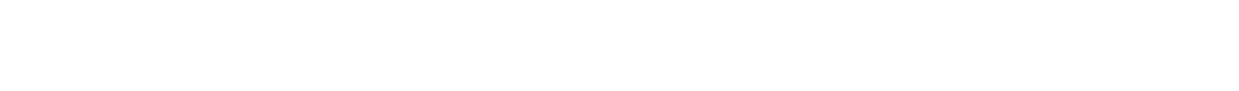

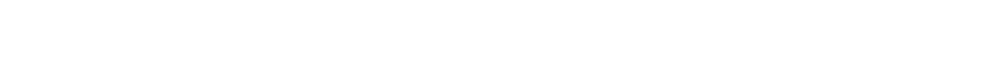

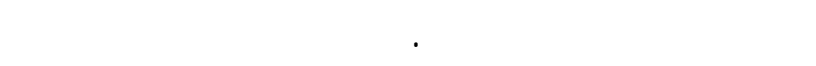

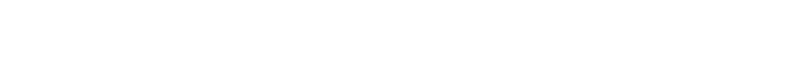

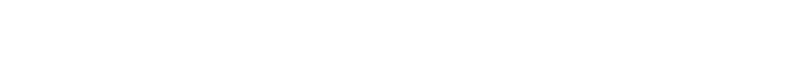

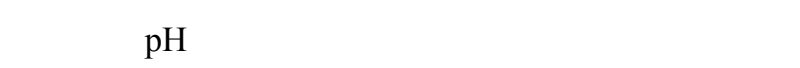

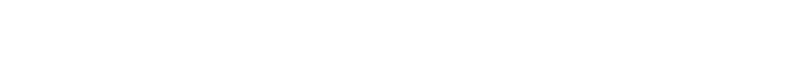

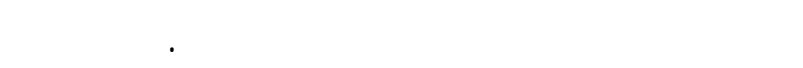

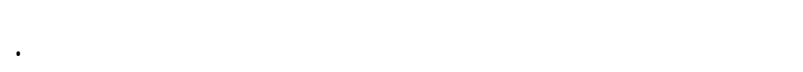

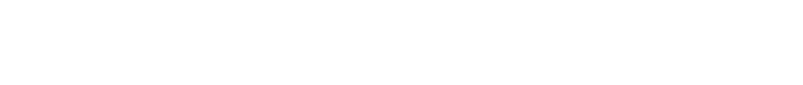

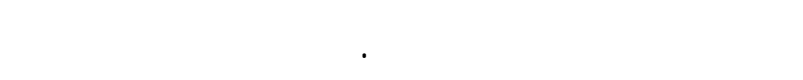

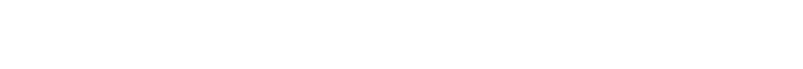
النخزن على ربة حرارة الغرفة.

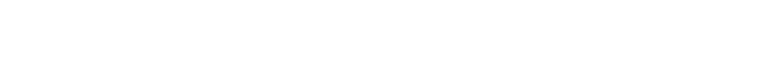

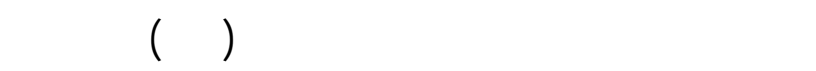
الصصل الأسلبي والعبودي للوقوف على القيمة الغذائة والقابلية

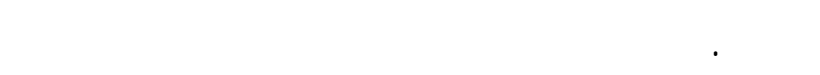

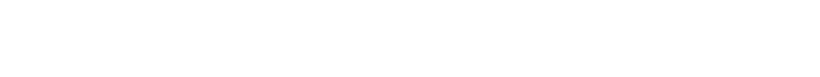

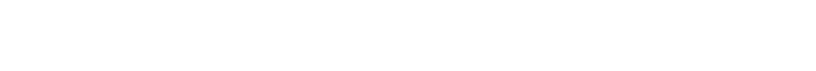

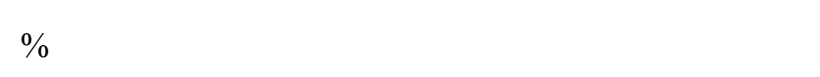

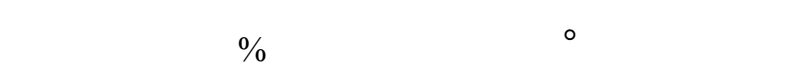

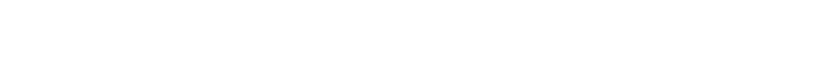

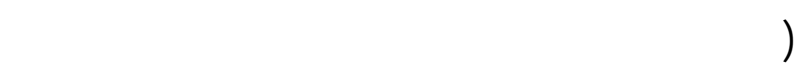

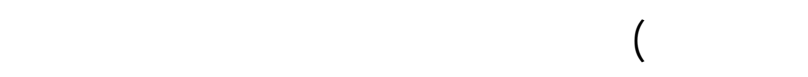

